\title{
Bibliometric phenomenon of Tamil Publications in Sri Lanka in 2005
}

The Author

\section{MAHESHWARAN, R}

BA (Hons.)(Peradeniya), MLS (Colombo)

Senior Asst. Librarian, University of Peradeniya

\section{Abstract}

Bibliometric analyses have been carried out in various fields. There has been no Bibliometric Study done on Tamil literature. This study evaluates the usefuiness of bibilometric application for the analysis of Sri Lankan Tamil Publications in the year 2005 only. This paper discusses the necessity of preparing a detailed bibliometric analysis of Sri Lankan Publications or analysis of same nature and prepares comprehensive complete bibliographical accounts of Sri Lankan Tamil Publications. It tries to provide an account on authors, publishers, geographical area of publishers and editor in Tamil /iteratry field. This study also evaluates the length, size, price and pagination of published Tamil publications in Sri Lanka. This study will 
urge the Tamils scholars and researchers or Post graduate students to start analyse of Bibliometric study on Tamil literature in Sri Lanka.

A total number of 65 authors have produced 77 Tamil publications which have been taken for this analysis. Out of 91 publications, $15 \%$ are edited publications. Most of the publications $40 \%$ is published in Colombo and the Traditional Tamil cities - Jaffna and Batticalo contributed $11 \%$ and $9 \%$ to the publishing field respectively. Most of the Muslim origin publications were published in the Eastem Provincial Region amounting to $15 \%$ and the Upcountry area contributed to the Tamil Publication with 16\%. $15 \%$ of the publications are brought about by the authors. Only 08\% publications were published by departmental or government funds. Two private publishers published 04\% of the publications each. Out of 91 publications printed in year 2005, $6 \%$ were published in length size of $21 \mathrm{~cm}$ and $29 \%$ in $22 \mathrm{~cm}$. There are 14 editors in 2005 and all editors edited only one publication each.40 of publication in Tamil literature $18 \%$ in religious and 10 in social science.

\section{Key words:}

Bibliometric Analysis, Tamil Publications, Geographical Area, Publishers, Authors 


\section{Introduction}

Sri Lanka is a South Asian country in the Indian Ocean with a very long history of human settlement. Over several thousand years people of various cultures have settled in Sri Lanka, or the so-called Ceylon and it is a process that has gone on until Independence. When the Island emerged as a newly independent country in the middle of the twentieth century, Sri Lanka was a multicultural, multilingual nation. From the Proto historic period, about 2500 years ago, there are two major ethnic groups, namely the Sinhalese and the Tamils, who started to evolve in the eighth century. There were also other minor groups who were assimilated into one or another major group in the course of time. With the arrival of Muslim traders, the third ethnic group evolved. The Mustim trader group is now known as the Muslims of Sri Lanka. Sri Lankan Muslims form one or a part of Tamil speaking population in Sri Lanka as their mother tongue is Tamil. During the European rule from the sixteenth century another ethnic identity - the Burghers started to evolve in the Sri Lankan ethnic community. During the European domination, under the Dutch, another minor group, the Malays, were brought from the islands of Indonesia. Finally, colonial rule and economic exploitation of the country by the British resulted in one more significant ethric identity, the Tamils of Indian origin. Tamils of Indian origin are also a part of the Tamil-speaking people. Hence, the members of Tamil speaking population, Indian origin Tamils, contributed to Tamil literature, which is presently identified as Hill country or Upcountry Tamil literary work. 


\section{Social background of Sri Lanka}

Sri Lanka is a multi-lingual, multi-ethnic, and multi-religious society. According to the population census of 2001, the total population of the country is $17,967,800$. The population distribution in Sri Lanka is $21.5 \%$ in urban, $72.2 \%$ in rural and $6.3 \%$ in estates. The major ethnic groups are the Sinhalese $(73.9 \%)$, Sri Lanka Tamils (12.7\%), Indian Tamils (05.6\%) and Sri Lankan Moors (07\%). Other ethnic groups are Burghers \& Europeans $(0.26 \%)$ Malaya $(0.32 \%)$ and others $(0.19)$. The larger portion of the Sinhalese are Buddhists and the majority of the Tamils are Hindus. The other two religions are Christianity and Islam. The religion wise distribution in Sri Lanka is given in table 1.1.

Table 1.1: Religion distribution in Sri Lanka

\begin{tabular}{|l|l|}
\hline Religion & Percantage \\
\hline Buddhism & 69.3 \\
\hline Hinduism & 15.5 \\
\hline Christianity & 7.6 \\
\hline Islam & 7.5 \\
\hline Others & 0.1 \\
\hline
\end{tabular}

Source: Department of Census \& Statistics 2001

The ethnic distribution in Sri Lanka is given in Table 1.2. 
Table 1.2: Composition of Population in Sri Lanka

\begin{tabular}{|l|l|}
\hline Ethnic Groups & Percentage \\
\hline Sinhalese & $73.95 \%$ \\
\hline Tamils & $12.70 \%$ \\
\hline Indian Tamils & $5.52 \%$ \\
\hline Sri Lankan Moors & $7.05 \%$ \\
\hline Burgher \& Europeans & $0.26 \%$ \\
\hline Malays & $0.32 \%$ \\
\hline Others & $0.19 \%$ \\
\hline
\end{tabular}

Source: Department of Census \& Statistics 2001.

\section{History of Sn' Lankan Tamil Literature}

The inception of the modern Printing press in Tamil dates back to about 1830, when some Christian missionaries came out with a monthly journal in India. Somalay, (1955) stated that the first daily newspaper in Tamil Swadesamitran-was founded in the last quarter of the 19 in century in India and the editor was Mr. G. Subramaniam lyer. The first publication brought about in Sri Lanka was the Government Gazette in Tamil, Sinhala and English. It came out in 1802. The First English Journal 'Colombo Journal was founded in 1832. Although India has influenced Sri Lanka in many ways, Sri Lanka has produced Tamil literary works, specifically Sri Lankan. India and Sri Lanka have different colonial experiences and this perhaps is the most significant reason why an identifiably Sri Lanka tradition in Tamil literature was born.

Ever since historic times, Sri Lanka has been contributing much to the growth of world Tamil language and literature. Poets from the Northern and Eastern parts of Sri Lanka, now known as Jaffna and Batticalo respectively, have tremendously contributed to Tamil Literature and Tamil language in Sri Lanka. Some researchers believe that the poet llatthu Puthanthēvanār 
(Before $3^{\text {rd }}$ Century AD) who composed seven verses in the Chankam anthology is believed from Sri Lanka. Scholars are of the opinion that the Chankam poet Iddaikkader also hailed from Ceylon. There is a village called by the name of Iddaikkaddu in the Jaffna Peninsula and there are some individuals who have the same name as Iddaikkader among the Sri Lankan Tamils. From Chankam period up to the time of Aryachakaravarthis (The Monarch of Aryar), there is a gap in the history of Tamil Literature in Sri Lanka. Even during this period, there is evidence to say that the Tamils occupied various parts of the Island from Point Pedro to Deventra Head, and from Puttalam to Trincomalee. From the time of Elala (Second century B.C) up to the last king Sankili who was killed in the hands of the Portuguese in 1621, Tamil kings have ruled over Ceylon. Some have ruled over the whole island and at other times over parts of the country. Tamil inscriptions have been discovered in various parts of the Island.

In thirteenth century, Aryachakaravarthis, who were great patrons of learning, estabiished the Jaffna Kingdom. Many outstanding works were produced during the régime of Aryachakaravarthis, which are traceable from fourteenth century A.D. to modern times. Varatharajan. Mu (1988) in his publication stated that in the sixteenth century, the poet Aracakechari translated Kalidasa's Raguvamsam into Tamil, which is an epic containing 2,400 verses. There are so many minor works like thalapurānams (sacred places, ancient legend or traditional history), kõvaí (Stringing, arranging, a kind of poem expressing the feeling of love), Ula (a poem about the hero arriving in Procession), Kalampakam (a poem of different kinds of stanzas), chatakam(a poem of hundred stanzas), Thūthu (message, poem of message to...) and anthāthi(composing stanzas in a way where the last part of the previous stanza becomes the beginning part of the next). The conquest of the marine-provinces of Ceylon by the Portuguese in the sixteenth century and by the Dutch in the seventeenth century, leads to the arrested growth of Tamil literature. Even during this period, Gnanpragasar from Thinneveli, Jaffna went into exile in India. He was an erudite scholar in Tamil and Sanskrit and composed and wrote one of six commentaries on 
Sivgnana siddhiar. Varatharajan. Mu (1988) said that up to the eighteenth century Tamil was the language of bureaucracy in Sri Lanka and many Singhalese learnt it. Even in the recent past Singhalese chieftains signed treaties with the British in Tamil. Ārumuga Nāvalar (A.D. 1822-1889) occupies the pride of place among the Tamil scholars of Yāppānam. Nāvalar was instrumental in starting a printing press to bring out quality Tamil textbooks. He was in fact, the forerunner in printing Tamil textbooks without mistakes. In Nineteenth century, Nāvalar set the pace by writing chaste, faultless and simple Tamil. C.V Thāmōtharam Pillai's services as the first editor and publisher of old manuscripts written on palm leaves are remembered by the Tamil-speaking world even today. The poet Navāliyūr Cómacuntharam Pulavar composed more than 15,000 verses and became famous for this devotional poems on Lord Murukan, the presiding deity at Katirkāmam, now known as lord of Katharagama and also wrote interesting poems on festival celebrated in the Tamil month of Adi (Month of July).

The establishment of the printing press in 1736, in Colombo created a new era in the literary history of Sri Lanka. Pulendran. $G$ (1998) said that simple catechisms in Tamil and Sinhala languages were printed and distributed to schools, churches and other institutions. Christian missionaries came out with a journal in Tamil in 1841, which was referred to as 'Uthayatharakal.

The maritime provinces of Sri Lanka passed into the hands of the Dutch from the Portuguese in 1658. The introduction of the western form of school system was due to the influence of Portuguese Missionaries, and they had used the schools to introduce the religion to the native children. During this period, one can see the emergence of standard Christian literature and some outstanding Tamil literary works were written by scholars like Poologasingha Mudaliyar, Koolankaithambiran, Francis Pillai etc. According to the Tamil Catholic literary Tradition of Sri Lanka (1998), Tellipalai was the centre of the Catholic literary activities. Civakurunathan (1993) wrote in his article as "Works of Hindu literature of very high standard, which could be compared with the compositions of Nayakka period in South india, 
emerged in Sri Lanka during this period. Some of these works centered around the lives of eminent individuals and temples, satisfied the needs of the people"

The pioneers among Tamil publishers in Sri Lanka were the missionaries. The First publishers were the Dutch, and the church missionaries followed. Henry Martin and Seth Sabasen were the editors of the first published journal in both English and Tamil languages in 1841 as a weekly magazine. Murugappa and Philippaiah were the editors of the Journal 'The Jaffna Catholic Guardian' (In1876) and Eurrelu S.Savanamuthtu Pillai was the editor of the journal, Saiva Uthayabannu, which was published as Journal for Hinduism in 1916, Achuveli. S. Thampimuthtu chettiyar was the editor of Cannmarkapothani (1885), T.P.Sellaiah Pillai was the editor (1889) of 'The Hindu organ' and M.C.Sidhilebage was the editor of the 'Mu/see/m Necen' (Muslim Friend 1882), Cannmarkapothan/(1885).

The first printing press was brought to Sri Lanka, during Governor Willem Baron Van Imhoff period in 1736. Printing started in the press in 1737. By 1739 the first publication Samaya vinavidaium sebanka/um was printed in the first press. As there was another printing press established little later, at the end of Governor Baron Van Imhoff period, more than twenty Tamil works were published. It was believed to be the first printing press established in the Northern region of Sri Lanka and Father Joseph Knight published 'Muttivali'. The establishment of the printing press resulted in the creation of eminent publishers among the natives in Sri Lanka. Navalar and C.V.Thamotharanpillai $(1832$ - 1901) were the most popular and eminent publishers in nineteenth century. It is worthwhile to mention the other prominent publishers, S. Thamppimuthup Pillai (1857-1934) and Valvai S.Waithilingam Pillai (1843-1900)

When Arumuga Navalar realized the advantages of the establishment of printing presses for Christians in Sri Lanka, he too established a printing press in Nallur in 1879. The First printing press was established in the 
name of 'Vittiyanupalanyantrira salai' as a native printing press in Northern Sri Lanka. Then the press was transferred to Vannarpannai. Through the printing press being established by natives in Jaffna, many newspapers and Journals were published in Tamil. There were so many weekly and monthly Journals published in Tamil and there were some papers and weekly journals published and the two Native Tamil Scholars were the editors of the publications. Many books were brought out to improve the Tamil language and the native religions.

\section{Sri Lankan Tamil Publications}

Christian Missionaries in Sri Lanka published the Christian Journal 'Chaththiya vetha paathukavalan' in 1859. The first publication in Sinhala 'Lankaloga' came out in 1860 and the editor was Rev. Dharmalangara Thero. The first journal of Tamil speaking Muslims was founded in 1882 in the name of 'Muslim Nechan' and the 'Mulseelm Necen' (Muslim Friend 1882) was brought about as in a manuscript form at the beginning and then the printed form came out. Only in 1948, the Tamils of Indian origin Tamil publication come out from Upcountry where they were continuously concentrated and settled. It was 'Bharathy and the editors were K.Ramanathan and K.Ganesh. The first university journal published in Sri Lanka was the 'Elankathir' in 1948 and the first agricultural and scientific journal brought about was 'Kamatholzil velakkam', which has been published by the propaganda unit of the Agriculture Department in 1930.The present Daily newspapers 'Thinnakaran; 'Veerakeechary', 'Chuthanthiran' were founded weekly at the beginning and then converted as daily papers. Now, there are seven Tamil daily newspapers published in Sri Lanka.

Some translated books too were published despite the fact that there is controversy regarding the translation, whether it should be literal or literary. Perhaps Rev. H. Hoisington, who rendered the 'Sivagnanapotham', 'Tattuva Kadda/s/, and 'Sivapirakasam' into English in 1854, did the earliest known 
translation of Classical Tamil in Ceylon. It deserves to be mentioned that Rev. Issac Thambiah translated Sage Thayunanavar in the nineteenth Century. The first published translated book was Kalidasa's 'Raguvamsam'. In the sixteenth century, the poet Aracakechari translated Kalidasa's Raguvamsam into Tamil. K.Ganesh from upcountry translated the English Novel written by Mulrajah Ananth into Tamil and published before the year 1940. The English drama 'Pathmashanee' and 'Theayilai Thoddaththilae' ('In tea estates' Hill country'- essays), both written by C.V.Vellu Pillai were published during the same period. By 1950, So many publications were brought out from Up Country, for instance 'Kankanee mahal, 'Oru thulit kanneer etc.

The missionaries who came to Sri Lanka to work in Tamil, realized the importance of a Dictionary, and the scholar from Church missionary Rev. J Knight started the compilation of Tamil words in to a dictionary. In 1842, the American missionary, published a Tamil Dictionary, containing 58, 500 words. Later it was known as 'Jaffna Dictionary' and 'Mannipai Dictionary'. It was the first dictionary published in Tamil. In 1862, a Tamil-English dictionary was brought about with the cooperated work of Weerasamy Chetti, Vesaka Perumalayar, Ramanua Kavirayar and others under the purview of Rev. Vencillo. It contained 67,452 words and 979 pages. Other scholars who compiled and published dictionaries were Vaymen Kathiravet Pillai, Chunnakam Kumarasamy Pulavar, Navalar Kooddam Muthuthampi Pillai and Point Pedro Subramaniya Sasthiriyar.

The Tamil literary scholars, who could not find proper grant or financial assistance from Sri Lankan government or any type of Sri Lankan funding or grant and for other reasons, published their literary work in India due to the main reason of cheap production cost. It only means that it was the Sri Lankan original literary work that was published in India. These publications are also presently considered as Sri Lankan Publications. 


\section{Statement of Problem}

Detailed studies have not been done on the history of Tamil publications in Sri Lanka. There is hardly any document on any comprehensive bibliography of Tamil publications. Due to the absence of bibliographical documents on Tamil publications or bibliography on Tamil printed publications, researchers who search for information on Tamil culture and literature face difficulties to trace suitable references, specially, information about publishers, printers, etc. Some scholars have mentioned about publications and the authors but there was hardly any information about the printers, press and publishers.

Tamil literary work done during the past has been destroyed or lost due to the war situation that prevailed in the North and East during the last 50 years. Furthermore, many publishers who had contributed immensely to Tamil culture and literature have also vanished from the scene. Therefore, researchers cannot find necessary bibliographic details for their research work.

It would be worthwhile to trace the prominent printing presses that contributed to bring out valuable Tamil literature. So, that the publishers and the editors have been rendered a valuable service to Tamil could be identified. Now the intellectuals have realized that the bibliography of publishers and editors would be useful to the future generations of Sri Lanka.

\section{Literature Review}

During the process of literature survey, it has been observed that various aspects of Bibliometric studies and the importance and use of Bibliometric study in various fields. But no effort has been made towards a Bibliometric 
study of literary work in Sri Lanka. Review of literature for present research work has been done through all sources l.e. online search, e-books, conference proceedings, indexing, abstracting periodicals, books etc. To be clear about the concepts involved in this issue intensive keyword search has been done online. Some books in this area and some websites, which give information on this subject, are as follow;

In a study by Cheng Huanwen (1996) which modeled research paper on studies done by Jaevelin and Vakkari in 1990 and 1993, analyze the Library and Information Science (LIS) research in China from 1979 to 1994. The aim of the paper is to study how research articles were distributed over various topics. It is to analyze the research methods applied and the similarities and differences between LIS research in China and in the world.

In an article Clement.S. et al (2003) analyzes the relationship between research publications and funding databases to the amount of research activity on different illnesses - particularly on Bipolar Disorder.

In a study Jacobs (2001) discusses the Bibliometric study of publication patterns of selected groups of academics of ten universities of South Africa for a period of five years. The Subjects fields surveyed are Physics, Chemistry, and another three.

Estrada Lorenzo et al (2003) in their article evaluate the authors by their geographical areas of residence and the type of institutions that they are employed. The aim of the paper is to analyze the geographical spread of the authors and the institution by which they are employed.

Gopal and Mall (2004) in a paper discuss about the importance of Hindi as mother tongue and the role of education and research for Hindi speaking 
users. It also emphasizes the importance of Hindi subject glossaries from information retrieval to Hindi speaking users.

Lazarev et al (2000) in their paper deal with the ontological information in the medical discipline. The information highly scattered in about 100 specialized periodicals and in more than 2,500 other periodical titles that publish articles is devoted to cancer problems and more than 3,500 periodicals cited by Oncologists. The article reviews the conversely of Bibliometric analysis on oncology literature, features and the characteristics of documentary information, flows under studies and the main findings.

Mela et al (2003) evaluate the number and scientific weight of papers written by European radiologists. The Bibliometric study is used to compare European radiologists with colleagues from other countries, to measure the contribution of European researchers to radiology journals and to correlate Bibliometric parameters with some socio-economic factors of the European nations

Parvathamma (1993) evaluates usefulness of bibliometrics as a viable and distinctive research technique to evaluate the science of science based on bibliographic and citation data. In addition, the paper presents various definitions of the term 'Bibliometrics'. The application reviews the usefulness of the technique in following aspects:

1. Growth rate of Literature

2. Scientific Productivity of authors

3. Collaborative trend among the authors

4. Core journals

Rawat and Kumar (1992) state "Bibliography is about books, which is as defined by Walter Greg 'the study of books as material objects'. Primary bibliographic function is simple listing of individual items, and it becomes known as enumerative or systematic bibliography. It is especially important 
with collections and doubly so when these collections are designed to serve the needs of groups rather than of individuals. The next step forward in bibliographic studies is probably the most significant of all, which was brought forward in the nineteenth century, particularly in England, and resulted in a much deeper understanding of bibliographic problems which a book can pose. Henry Bradshaw (1831-1886) proved to be a major turning point in bibliographic situation, not simply because of his own work but also because of a key figure accepted by many scholars throughout Europe as the source of reference. The impact of his work is such-powerful that a new field of bibliography, begins to emerge. Enumeration frequently demands no more examination of the book than is sufficient to reveal the fundamental information of author, title, and place and date of publications. Out of Bradshaw's methodology, it also introduced the techniques of analytical or critical bibliography. As time grew, the Textual bibliography and historical bibliography also developed. It is a profession in which what is recorded, by whatsoever means the historical development has permitted, is the foundation of all activity"(p.125-134).

In a study Webster (2004) evaluates the degree of presence and potential impact of ethnic minority Scientists on UK Science. The issue examines their published works. It is mentioned in the paper that in the last twenty years the proportion of ethnic-authored papers almost doubled.

In a paper Glanzel and Schepflin (1999) analyze literature in the Sciences and Social science articies.

Bibliometric study is particularly related to research in scientific communication. Schmidmaier (1984) discusses the history of Bibliometric and demonstrates its relations to the concept 'the science of science'. The idea trace to lecture delivered by Carl Christian Friedrich Krause in 1829. The first genuine Bibliometric investigation was published in 1917 by Cole and Eales. In European information science journals Bibliometric 
analyses became popular in the 1970 s and in the 1980 s in Hungary. Eastern Germany and Switzerland, which belong to Europe. The scholars of these countries started early to do research on the subject. The Asian countries started late to adapt the literature analysis bibliometrically.

\section{Research Methodology}

identification of the problem has been done keeping in the view of the information needs of Tamil intellectuals. The information for this article will be based on data sheet filled by the researcher and the information gathered only from National Bibliography. Pamphlets, Textbooks and other publication for School going students, books published for various exams are not taken for the analysis.

\section{Objectives of the study}

The research has been undertaken to urge the academic researchers and undergraduates and post graduate students to carry out Bibliometric analysis and evaluative information on Sri Lankan Tamil literary works published in Sri Lanka and the pioneer literary scholars of the nation who have been engaged in publishing Tamil Books. There are several reasons to undertake this topic. It would be worthwhile to trace the prominent printing presses and publishers who have contributed to bring out valuable Tamil literature. To my knowledge, no literature survey of this kind had been carried out, thus, it would be the first study of this nature in Sri Lanka.

The main objective of this article is to make a bibliographic analysis of published Tamil literature in the year 2005 and to provide critical analysis of application of Bibliometric analysis of the origin development and growth of publication Tamil literature in Sri Lanka. Here it is to evaluate the contribution of various groups of Tamil specking populations to Tamil literature and the language; it is also one of the main objectives of the study, to compile the bibliographical account on the publications of Tamil in 
Sri Lanka. It is very important to evaluate the printing of Tamil publication work and the development of publishing works.

It is also the objective of this study to provide information about the authors, editors, publishers and printers of Tamil publications in the nation, and the relationship of various ethnic groups and various regions of the country on Tamil Publications. It is also a study of information on Tamil publications in Sri Lanka in the year of 2005. Research of this nature on the Tamil literature in Sri Lanka has not been undertaken hitherto, and in view of the present importance of Tamil literature and cultural research activities, it is worthwhile to consider how to compile a broad account of Tamil Publications in Sri Lanka.

The specific objectives are as listed below:

\section{Specific objectives}

- To identify information about Tamil literary works in Sri Lanka and evaluate the development of literary works in the year 2005.

- To identify the authors of Sri Lankan publications during the Study period and to evaluate the authors according to the ethnic groups.

- It is also an important objective to analyze Sri Lankan Tamil publications according to subject (DDC) classification.

- To identify and analyze the length size of publications during the study period.

- To study the Publisher wise distribution during the study period

- To analyze the publishers based on Geographical areas distribution.

- Finally to make a Bibliomatric analysis on Tamil Publications in Sri Lanka in the year of 2005 . 


\section{Significance of Study}

To my knowledge, a study of this nature has not been carried out in Sri Lanka to date. Therefore, it is expected that this will pave ways and means for similar studies in future. It is also possible for a reader to acquire information about History of Tamil Publications in Sri Lanka. The findings of this study will lead to comprehensive bibliographical document of Tamil Publications for the future generation of literary research.

\section{Limits of the study}

The limits of the study are related to the selection of publications. The study is extended to selected Tamil publications, which are included in National Bibliography. The study is limited to one year - 2005 within the geographical area of Sri Lanka origin writers and intellectuals those who published in Sri Lanka and India and the publications, which are included in National Bibliography. The books and Publications aimed at schooling students and various government organized or formulated examinations such as GCE $(\mathrm{O} / \mathrm{L})$ and children's literary works, School text books and publications of the Ministry of Education Publication Unit, private presses and other government presses were excluded from the analytic materials. Other Publications excluded from analytic materials are listed Guides, Article indexes, Conference proceedings, Parliament and Provincial councils' debates, speeches and proceedings, Parliament and Provincial council Reports and Ministry, Boards, Departmental administrative reports, Trade \& financial Reports, Pamphlets, audio-visual material, Hand books, central bank reports, Sri Lankan UNO news publications. Election reports, Bibliographies, various souvenirs published for sports, death commemoration and religious worship functions, drawing, cookery, practical books, alphabets, mathematical and other work books and children books are also excluded from the analysis. 


\section{Results and Discussion}

The figures of total publications published in the past years were based on data from the Department of National Archives (2004) appeared in the Statistical Abstract. Total number of titles published in 2001 in Sri Lanka was 2005 and 428 in Tamil, 503 in English and 1074 in Sinhala. There are 326,159 copies printed in 2001 and 9, 46, 021 printed in 2002. Here, only the First Edition publications are included. The reprinted publications were not counted. The titles printed in two or more languages were 377 and 58,100 copies were printed in 2001. According to Department of Censures and statistics (2004) 51,018 copies were printed in 152 titles in two or more languages in 2002. Total number of titles of Educational textbooks designed and printed in 2001 was 62 and copies printed were 29,71,821; the same category printed in 2002 was 34 and $21,41,400$ copies respectively. The figures for $2003 \& 2004$ do not appear in any reliable reference sources. But for this research, the total Tamil publication published in the year 2005 , which was 748 , which was counted, based on the National Bibliography. According to the Methodology, objectives and limits of the study, only 91 publications were taken for the analysis.

\section{Rank List of Authors}

The authors' rank list of Publications in SriLanka in 2005 is given in table 1.3. Total number of authors of 65 (Including four co-authors and 57 individual authors; in four books authors are not mentioned), produced 77 Tamil publications that were taken for analysis. Here out of 65 authors 7 authors were in top list. Other 58 authors produced only one publication each. In four publications author's names were not mentioned. Out of 91 publications, $15 \%$ are edited. After 1983, when the ethnic conflict intensified, the dispersion of SriLankan Tamils was also growing, in togetherness consolidated by struggle and suffering and, given purpose and direction by the aspiration of a people for the future. The Publications of 
Tamil Diaspora were printed in all over the world. The Tamil literary scholars, who could not find proper grant or financial assistance from Sri Lankan government or any type of Sri Lankan funding or grant and for other reasons, published their literary work in India due to the main reason of cheap production cost. It only means that it was the Sri Lankan origin literary work, which was published in India. These publications are also presently considered as Sri Lankan Publications. But these publications were not included in the National Bibliography. It is worthwhile to mention that the Sri Lankan Tamil Diaspora literature also can be considered Srilankan Tamil Publications.

Table 1.3 Authors' Rank List

\begin{tabular}{|l|l|l|l|l|}
\hline Ser.No & $\begin{array}{l}\text { Rank. } \\
\text { No }\end{array}$ & Name of the Author & $\begin{array}{l}\text { Frequ- } \\
\text { ency }\end{array}$ & $\%$ \\
\hline 1. & 1 & Muththukarupan Ramachandran & IIII & 04 \\
\hline 2. & 1 & Gunarasa.K & IIII & 04 \\
\hline 3. & & Unknown or Not Mentioned & IIII & 04 \\
\hline 4. & 2 & Gunanathan .O.K & III & 03 \\
\hline 5. & 3 & Pathamanathan.S & II & 02 \\
\hline 6. & 3 & Armartha Sharma & II & 02 \\
\hline 7. & 3 & Subramaniyam .V & II & 02 \\
\hline 8. & 3 & Muththumeeran S & II & 02 \\
\hline 9. & & Rameswaran.S & II & 02 \\
\hline 10. & & Mariyampillai. Ruban & 1 & 01 \\
\hline 11. & & Mayilvaganam . Mangayarkarachi & I & 01 \\
\hline 12. & & Kamalasegaram.K & 1 & 01 \\
\hline 13. & & Devathas . Thampiayaiah & 1 & 01 \\
\hline
\end{tabular}




\begin{tabular}{|c|c|c|c|}
\hline 14. & Nageswaran. Kanagasapapathy & 1 & 01 \\
\hline 15. & Sugumar. Jegan & 1 & 01 \\
\hline 16. & Siddek Nazeema & 1 & 01 \\
\hline 17. & Mazzar.M.I.M & 1 & 01 \\
\hline 18. & Punniyameen. V.M & 1 & 01 \\
\hline 19. & Senthinatha Aiyar . Sri & 1 & 01 \\
\hline 20. & Sivachchariyar Umapathy & 1 & 01 \\
\hline 21. & Sangarachchriya Suwami & 1 & 01 \\
\hline 22. & Pathmanathan.S\& Ragunathan. $N$ & 1 & 01 \\
\hline 23. & $\begin{array}{l}\text { Kanagalingam \& Chellaappa } \\
\text { Thiyagaraja }\end{array}$ & 1 & 01 \\
\hline 25. & Annar & 1 & 01 \\
\hline 26. & Gajeendran & I & 01 \\
\hline 27. & Ramachandran .M & 1 & 01 \\
\hline 28. & Puhari Nafeer & 1 & 01 \\
\hline 29. & Tharmalingam & $\mathrm{I}$ & 01 \\
\hline 30. & Thamariachevy & 1 & 01 \\
\hline 31. & Muththiah.M.P & 1 & 01 \\
\hline 32. & Suthagar.T & । & 01 \\
\hline 33. & Bazeer.M & 1 & 01 \\
\hline 34. & Siddek. Sakkiya & 1 & 01 \\
\hline 35. & Ponnanian. Niriwai & 1 & 01 \\
\hline 36. & Vivekananthan. $Y$ & 1 & 01 \\
\hline 37. & Kamalanathan .S.R & 1 & 01 \\
\hline
\end{tabular}


Journal of the University Librarians...... (Vol.11), 2007

\begin{tabular}{|c|c|c|c|}
\hline 38. & Fariha .M.F.M & I & 01 \\
\hline 39. & Hariputheen .A.J & 1 & 01 \\
\hline 40. & Tharmaraja .N & 1 & 01 \\
\hline 41. & Arulanantham & 1 & 01 \\
\hline 42. & Nagarajan . Anu.Y & 1 & 01 \\
\hline 43. & Gunasingam . T & 1 & 01 \\
\hline 44. & Kanapathippillai . $\mathrm{O}$ & 1 & 01 \\
\hline 45. & Thiruchandran .Chelvy & 1 & 01 \\
\hline 46. & Rameswaran . Chelvy & I & 01 \\
\hline 47. & Paleel .Hak. K.M.M & 1 & 01 \\
\hline 48. & Alesack. Muhamad & l & 01 \\
\hline 49. & Meeaathu .M.Y.M & 1 & 01 \\
\hline 50. & Sakathevaraja .V.S & 1 & 01 \\
\hline 51. & Ganesamoorthy.$S$ & 1 & 01 \\
\hline 52. & Ragunatha Aiyar . V & 1 & 01 \\
\hline 53. & Panndiyen SivaGangarunanalaya & 1 & 01 \\
\hline 54. & $\begin{array}{l}\text { Sarojini Arunasalam \& Selaththurai } \\
\text { Arunasalam }\end{array}$ & 1 & 01 \\
\hline 55. & Kannaiah Yoohi & 1 & 01 \\
\hline 56. & Happeeulah M.D & 1 & 01 \\
\hline 57. & Arabath Ottamavaddy & 1 & 01 \\
\hline 58. & Thiyagaraja .Thaya & 1 & 01 \\
\hline 59. & Sinnaththampy . M & 1 & 01 \\
\hline 60. & Sivasubramaniyam . V & 1 & 01 \\
\hline
\end{tabular}




\begin{tabular}{|l|l|l|l|l|}
\hline 61. & Sam . Daniel & 1 & 01 \\
\hline 62. & Saravanamuthu. Pakkiyasothy & 1 & 01 \\
\hline
\end{tabular}

Out of the books taken for analysis, 65 authors wrote 77 publications. 14 publications were brought out as products of editors. The Editors distribution given in the table 1.7. Two authors produced four publications each. In four publications, the name of the author was not mentioned. There was another author who published three books in 2005. Out of 91 publications published only two publications were the products of coauthors. The contribution of Muslims as authors for Tamil publications was $16 \%$. So, during the study period there were a few authors who could regularly bring out their works. It did not mean that there were a few successful authors. If one author could bring out his work through printers of his own or if he could find any reliable publishes or funding agency only he could become a famous or successful author. So the reasons for the lack of many famous authors is not due to the fact that there were very few authors, but due to lack of proper funding agencies or governmental funding or financial incapability of authors to published whatever they had written.

There were seven tops rankers who produced 19 Publications. The top rankers contributed $21 \%$. The Percentage of top rankers out of total authors was $11 \%$. In Sri Lanka there were only $11 \%$ authors who dominated the Tamil publication field. Others were new or growing authors. There were a few grown or famous authors among SriLankan Tamils.

\section{Rank List of Publishers}

There are 65 publishers who have published 91 publications, which were taken for analysis in this article. The authors brought about $15 \%$ of the Publications. It is meant that the authors published 13 publications. Out of 
91 publication only $08 \%$ of publications were published by departmental or government funds. Two private publishers published $04 \%$ of the publications each. There were sixteen top rankers who published 56 publications and contributed $61 \%$. A governmental organization contributed only $08 \%$ to Tamil publications. The Distribution of publishers in year 2005 is given in table 1.4 .

Table 1.4 : Rank list of Publishers of Tamil Publications in the year 2005

\begin{tabular}{|l|l|l|l|l|}
\hline Ser.No & $\begin{array}{l}\text { Rank. } \\
\text { No }\end{array}$ & Publisher's Name & Frequ-ency & $\%$ \\
\hline 1. & 1 & Author & XIII & 14 \\
\hline 2. & 2 & Dept of Hindu Culturar affairs & VIII & 09 \\
\hline 3. & 3 & Piriya Publication Publishers & IIII & 04 \\
\hline 4. & 4 & Kamalam Publishing House & IIII & 04 \\
\hline 5. & 5 & Centre for Alternative Policy & III & 03 \\
\hline 6. & 5 & S.Godaadagae Brothers & 111 & 03 \\
\hline 7. & 5 & Meera Publishing House & III & 03 \\
\hline 8. & 6 & Fithul Hihma & II & 02 \\
\hline 9. & 6 & Nathan Publishing & II & 02 \\
\hline 10. & 6 & PAFFREL Organization & II & 02 \\
\hline 11. & 6 & Centre of Women educational Research & II & 02 \\
\hline 12. & 6 & Sooriya Women Development Centre. & II & 02 \\
\hline 13. & 6 & Varaiarrukkappatta Chenthania Vattittam & 11 & 02 \\
\hline 14. & 6 & Suhap Publication & 11 & 02 \\
\hline 15 & 6 & Priya Publication & 11 & 02 \\
\hline
\end{tabular}


Journal of the University Librarians (Vol.11), 2007

\begin{tabular}{|c|c|c|c|c|}
\hline 16 & 6 & SouthEastern University & 1 & 01 \\
\hline 17. & 7 & National Library Documentation services & 1 & 01 \\
\hline 18. & 7 & Central College Jaffna & 1 & 01 \\
\hline 19. & 7 & $\begin{array}{l}\text { NalliaThruGnanasampanthar Artheenam, } \\
\text { Nallur. }\end{array}$ & 1 & 01 \\
\hline 20 . & 7 & Sothida prakasayantrira salai & 1 & 01 \\
\hline 21. & 7 & $\begin{array}{l}\text { Old Boys' Association of Karaveddy } \\
\text { Vikneeswara college,Karaveddy. }\end{array}$ & 1 & 01 \\
\hline 22 & 7 & Buruup Savuntharam Media centre & 1 & 01 \\
\hline 23. & 7 & Muslim Positive Pose & 1 & 01 \\
\hline 24. & 7 & Vithiya theepam & 1 & 01 \\
\hline 25. & 7 & Yâ! Thirunelveli Thmilesaikch chankam & 1 & 01 \\
\hline 26. & 7 & Lindula Upcountry Arts Bureau & 1 & 01 \\
\hline 27. & 7 & Chokkavalachcheri VInnayagar Kovil & 1 & 01 \\
\hline 28. & 7 & Platform for Alternate Culture & 1 & 01 \\
\hline 29. & 7 & Vavuniya Kalai Ellakkiya Nannparkal & 1 & 01 \\
\hline 31. & 7 & Sri Kayathri Peedam & 1 & 01 \\
\hline 32. & 7 & VihzuthuAttitral Mempataham & 1 & 01 \\
\hline 33. & 7 & Akkavilee. & 1 & 01 \\
\hline 34. & 7 & Daniel Memorial Publication & l & 01 \\
\hline 35. & 7 & Moonrawathu Manithan & 1 & 01 \\
\hline 36. & 7 & Vairamuthu & 1 & 01 \\
\hline 37. & 7 & Manimehalia & 1 & 01 \\
\hline 38. & 7 & Supram Publishing House & 1 & 01 \\
\hline
\end{tabular}


Journal of the University Librarians...... (Vol.11), 2007

\begin{tabular}{|l|l|l|l|l|}
\hline 39. & 7 & Eravur History Research centre & 1 & 01 \\
\hline 40. & 7 & Surangani Indepemdent Service & 1 & 01 \\
\hline 41. & 7 & National Science Association & 1 & 01 \\
\hline 42. & 7 & I.S.S & 1 & 01 \\
\hline 43. & 7 & Imtheyas Ahemed Publising House & 1 & 01 \\
\hline 44. & 7 & Thirumahal Publishing House & 1 & 01 \\
\hline 45. & 7 & Vairaman Publishers & 1 & 01 \\
\hline 46. & 7 & Uma Publishing House & 1 & 01 \\
\hline 47. & 7 & Batticalo Eluthalar Oukkevippu Maiyam & 1 & 01 \\
\hline 48. & 7 & National Publisher & 1 & 01 \\
\hline 49. & 7 & Eeram Publishing House & 1 & 01 \\
\hline 50. & 7 & Shama Publishing House & 1 & 01 \\
\hline 51. & 7 & Human Development Organization (HDO) & 1 & 01 \\
\hline 52. & 7 & Meera Umma Publishing House & 1 & 01 \\
\hline 53. & 7 & All Ceylon Gandhi Seva Chankam & 1 & 01 \\
\hline
\end{tabular}

Rank order on the Basis Of Geographical area Of Publications

The distribution of geographical area of Tamil publications was given in Table 1.5. Most of the publications i.e $41 \%$ were published in Colombo city of SriLanka where there had been many printers and other printing facilities available. In Colombo there are about $10 \%$ of the SriLankan Tamils and $5 \%$ of Indian Tamil and $8 \%$ of SriLankan Muslims concentrated. Another $11 \%$ published in Jaffna, the Capital city of Northern Province where most of the 
Tamils are concentrated and which is the traditional Tamil city, Another 94 of the publications is published in the Eastern capital and one of the traditional Tanil cities Batticaloa. Most of the Muslim origins Publications were published in the Eastern Provincial Region amounting to $15 \%$. Upcountry Tamils or Indian origin Tamils concentrated Upcountry area contributed to the Tamil Publication with $16 \%$. Here, some of the Muslin or Islamic publications are also included.

Table 1.5. Rank of geographical area of publications

\begin{tabular}{|c|c|c|c|c|}
\hline Ser.No & $\begin{array}{l}\text { Rank. } \\
\text { No }\end{array}$ & Place of Publisher & Frequency & $\%$ \\
\hline 1. & 1 & Colombo & $x \times x y$ & 40 \\
\hline 2. & 2 & Jaffna & $x$ & 11 \\
\hline 3. & 3 & Batticaloe & VIII & 9 \\
\hline 4. & 4 & Kandy & $\mathrm{VI}$ & 7 \\
\hline 5. & 5 & Not Mentioned & $\| 111$ & 4 \\
\hline 6. & 6 & Oluvil & $11 \mathrm{I}$ & 3 \\
\hline 7. & 7 & Kinniya & II & 2 \\
\hline 8. & 7 & Udathalavinna & II & 2 \\
\hline 9. & 7 & Valaiachenai & $\|$ & 2 \\
\hline 10 & 8 & Kokuvil & 1 & 1 \\
\hline 11. & 8 & Nuwara-Eliya & ] & 1 \\
\hline 12. & 8 & Lindula & 1 & 1 \\
\hline 13. & 8 & Kuppları & 1 & 1 \\
\hline 14 & 8 & Nugagoda & 1 & 1 \\
\hline
\end{tabular}


Table 1.6 Distribution of size of the Publications

\begin{tabular}{|c|c|c|c|c|}
\hline Ser.No & $\begin{array}{l}\text { Rank. } \\
\text { No }\end{array}$ & $\begin{array}{l}\text { Length Size of } \\
\text { the Publication } \\
\text { (in } \mathrm{cm} \text { ) }\end{array}$ & Frequency & $\begin{array}{l}\text { Percentage } \\
\%\end{array}$ \\
\hline 1. & 5 & 17 & IIII & 06 \\
\hline 2. & 3 & 18 & IX & 10 \\
\hline 3. & 4 & 19 & $V_{1}$ & 07 \\
\hline 4. & 5 & 20 & IIII & 06 \\
\hline 5. & 1 & 21 & $X X X I$ & 34 \\
\hline 6. & 2 & 22 & $X \times V$ & 27 \\
\hline 7. & 7 & 23 & II & 02 \\
\hline 8. & 8 & 24 & 1 & 01 \\
\hline 9. & 8 & 25 & 1 & 01 \\
\hline 10. & 7 & 26 & II & 02 \\
\hline 11. & 8 & 28 & I & 01 \\
\hline 12. & 7 & 29 & 11 & 02 \\
\hline 13. & 6 & 30 & III & 03 \\
\hline
\end{tabular}

\section{Rank List of Editors}

The distribution of the 2005 publications editors is given in Table 1.7. Only $15 \%$ of publications were edited. There are 14 editors in 2005. All editors edited only one publication each.

Table 1.7 The distribution of Editors 


\begin{tabular}{|l|l|l|}
\hline Ser.No & Editor of the Publication & Frequ-ency \\
\hline 1. & Rasaiah .Sritharan & 1 \\
\hline 2. & Lianel Gurukae & 1 \\
\hline 3. & Uonuel Alliyar & 1 \\
\hline 4. & Pathmanathan .S & 1 \\
\hline 5. & Pathmamatham . S\& Ragunathan. $\mathrm{K}$ & 1 \\
\hline 6. & Chelvy .Thiruchandran & 1 \\
\hline 7. & Thirugnansundaram .V.A & 1 \\
\hline 8. & Ragunathan. K & 1 \\
\hline 9. & Paereenpanayagam T & 1 \\
\hline 10. & Bousatheen M.I & 1 \\
\hline 11. & Thavaraja.V & 1 \\
\hline 12. & Vijayalaxsumy Segar & 1 \\
\hline 13. & Sri Visvanba Visalachchi Mathagee & 1 \\
\hline 14. & Sivagurunathan .S & 1 \\
\hline
\end{tabular}

\section{Prica list of the Publication}

The distribution of the price of the publications in the year 2005 is given in the Table 1.8. The price of $9 \%$ of the books was fixed as Rs. 150.00 each and another $9 \%$ was Rs. 250/=. Each. Another $7 \%$ of the books cost Rs. 100 each and Rs. 175.00 each. In $29 \%$ of the publications, the price was not mentioned. Same length size publications and same pagination were fixed different prices. The Prices were fixed by the publishers without any proper policy or coordination with government control. 
Table 1.8: Distribution of the Price of publications

\begin{tabular}{|c|c|c|c|}
\hline Ser.No & $\begin{array}{l}\text { Rank. } \\
\text { No }\end{array}$ & $\begin{array}{l}\text { Price of the } \\
\text { Publication }\end{array}$ & Frequency \\
\hline 1. & 5 & 30.00 & 11 \\
\hline 2. & 6 & 35.00 & 1 \\
\hline 3. & 6 & 38.00 & 1 \\
\hline 4. & 6 & 50.00 & 1 \\
\hline 5. & 5 & 60.00 & II \\
\hline 6. & 6 & 65.00 & 1 \\
\hline 7. & 6 & 70.00 & 1 \\
\hline 8. & 6 & 75.00 & 1 \\
\hline 9. & 6 & 80.00 & I \\
\hline 10. & 6 & 90.00 & $i$ \\
\hline 11. & 3 & 100.00 & VII \\
\hline 12. & 4 & 120.00 & III \\
\hline 13. & 6 & 125.00 & I \\
\hline 14. & 6 & 130.00 & 1 \\
\hline 15. & 6 & 140.00 & 1 \\
\hline 16. & 2 & 150.00 & VIII \\
\hline 17. & 3 & 175.00 & VII \\
\hline t8. & 4 & 190.00 & III \\
\hline 19. & 5 & 195.00 & 11 \\
\hline 20. & 1 & 200.00 & $x$ \\
\hline
\end{tabular}




\begin{tabular}{|l|l|l|l|}
\hline 21. & 6 & 225.00 & I \\
\hline 22. & 6 & 230.00 & 1 \\
\hline 23. & 2 & 250.00 & VIII \\
\hline 24. & 5 & 300.00 & II \\
\hline 25. & 6 & 350.00 & 1 \\
\hline 26. & 6 & 400.00 & 1 \\
\hline 27. & 6 & 450.00 & 1 \\
\hline 28. & 6 & 475.00 & 1 \\
\hline 29. & 5 & 500.00 & II \\
\hline 30. & 6 & 600.00 & 1 \\
\hline 31. & & Not mentioned & XVII \\
\hline
\end{tabular}

\section{Subject Classification}

Table 1.9 :Distribution of Publications based on DDC subject classification

\begin{tabular}{|l|l|l|l|l|}
\hline Ser.No & Rank & DDC Subject & Frequency & $\%$ \\
\hline 01 & 07 & Knowledge & I & 01 \\
\hline 02 & 07 & Computer Science & 1 & 01 \\
\hline 03 & 07 & Library Science & I & 01 \\
\hline 04 & 07 & Journalism & I & 01 \\
\hline 05 & 07 & Astrology & I & 01 \\
\hline 06 & 02 & $\begin{array}{l}\text { Religion } \\
\text { Hinduism 14 } \\
\text { Islam 02 }\end{array}$ & XVI & 18 \\
06.1 & 06.2 & Social Sciences & IX & 10 \\
\hline 07 & 03 & Political Science & III & 03 \\
\hline 08 & 05 & & & \\
\hline
\end{tabular}




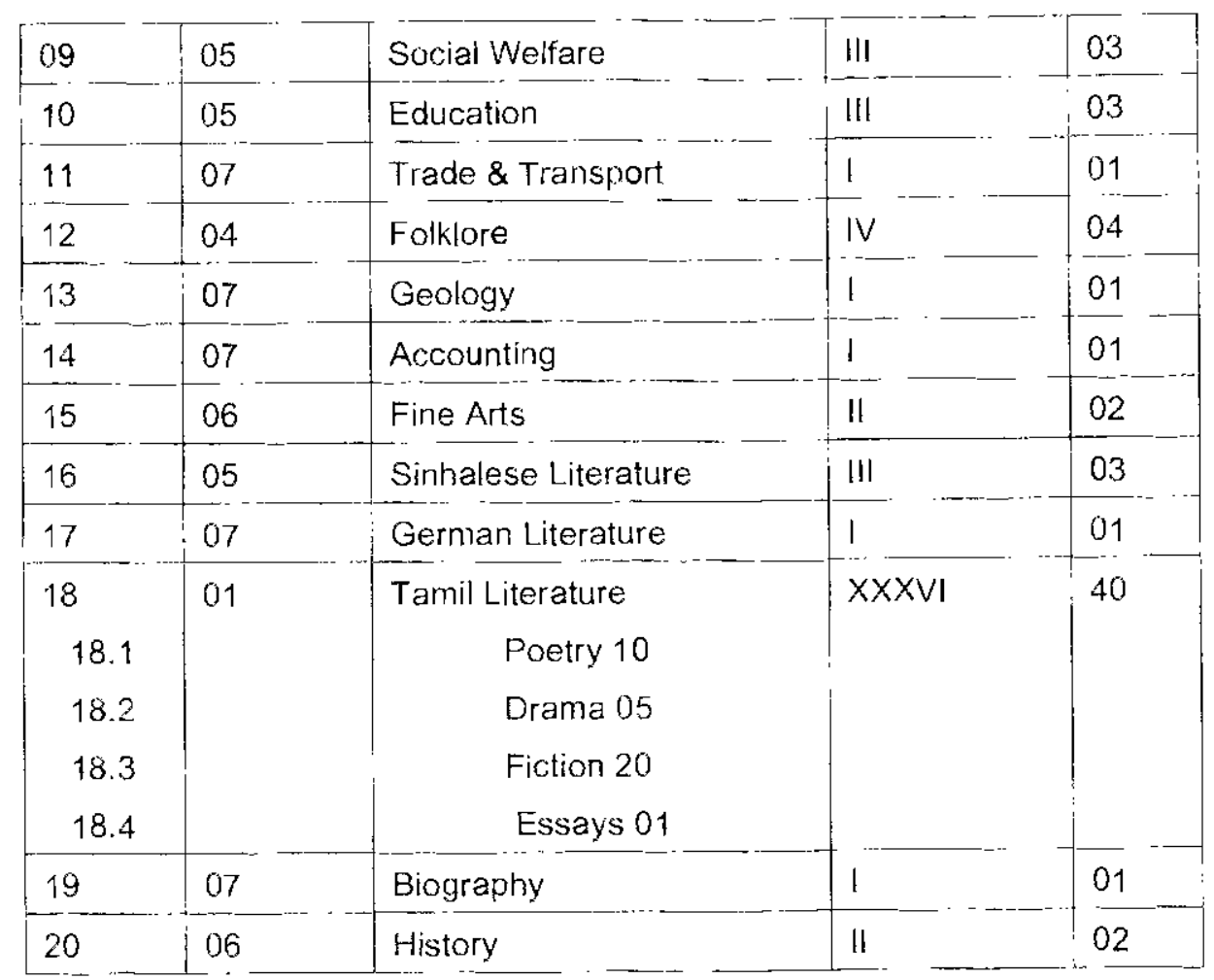

Distribution of subject classification of publication of 2005 , was given in Table 1.9. Classification of publications was done according to the National Bibliography subject classification. Out of 91 publications, 16 religious publication published in2005. 18\% of total publications- religious publications 02 publications in Islamic books, the rest publications in Hinduism and there was no publications in other religions-Christianity or Buddhism. There are $40 \%$ of publications in the Tamil literature, out of 36 publications in Tamil literature subject classification 17 publications in short stories and 03 are novels. There are 10 poems. 05 dramas and one essay. Publications in social science are analyzed. There are 02 about peace, 03 about conflicts and 03 in social groups. There are two publications about Tsunami in Social welfare subject. There are 06 folklore publications: out of those 06 publications, two publications about Sinhala folklore and the rest about Tamil folklore. 


\section{Conclusion}

The present study evaluates the Tamil literary work published in the year 2005. The publisher analyses and the author analyses give reasonable and reliable accounts on the Publications brought out in 2005. This short study provides limited accounts on the Sri Lankan Tamil Publications in Sri Lanka with so many limitations. This study will urge the Tamil Scholars and researchers or Post graduate students to start analyses of Bibliometric study on Tamil literature in Sri Lanka. It would be worthwhile to mention that this is the first study of this nature in Sri Lanka.

\section{References:}

Cheng Huanwen (1996) A Bibliometric study of Library and information research in China: Proceeding of the 199662 nd IFLA General Conference held in China.

Civakurunātan.l (1993) /lankaiyil Tamilp Puthinap palthirikaiyin valarcci. Colombo, Colombo Tamilch Chankam.

Clement, S. et al (2003) Status of Bipolar disorder research: Bibliometric study. The British Journal of psychiatry, 182, 148-152.

Estrada Lorenzo J.M. et al (1991-2000) Bibliometric study of original Article in the Revista

Española dr Salud Públicc- Part ll: Authors' Productivity, Their institutions and geographical areas., Revista Española de salud pública.,2003 MayJun; vol 77(3), pg 333-346.

Gopal Gang Ram, Mall B,(2004) Importance of subject glossaries in Hindi language to understand the needs of Hindi speaking users and their 
Bibliometric study . Responding to users' need in changing information landscapes: Sojourn of Library from palm-leaf to palm-top ): Delhi, Indian Library Association.

Jacobs, Daisy. (2001)A Bibliometric study of the publication patterns of scientist in South Africa 1992-96, with particular reference to status and funding. South Africa, University of Pretoria.

Lazarev, V.S. et al (2000) Review of biblometric studies of the literature in Oncology and ad hoc study of documentary information flow in Leukemia Treatment and prognostication of Leukemia development, Belarusian state Polytechnic Academy.

Mela, G.S., et al (2003) Radiological research in Europe: A Bibliometric study in European Radiology. 13 (4), 657-662.

Parvathamma, $\mathrm{N}$ (1993) Bibliometrics-lts prigin and Application; (Current studies in Library and information Science.) Delhi, Manak Publication Pvt.Ltd. p.657-662.

Pilendran G. (1998) Tamil Catholic Literary Tradition of Sri Lanka.In. Viyakula Pirasangam Vol-1. Colombo. Catholic Student Union. P.21.

Rawat, P.P. and Kumar, T. (1992) International Encyclopedia of information Technology \& Library Sciene. Vol. 1 New Delhi, Castle book private limited. p. 125-134.

Somalay (1955) A Brief Survey of the Tamil Press. Tamil Culture , IV(2) Statistical Abstract, (2004) Department of Census and statistics.

Varadarajan, Mu.(1988) A History of Tamil literature. New Delhi, Sahitya akademi 
Webster,et al(2004) A Bibliometric analysis of presence and impact of ethnic minority researches on science in the UK, Research Evaluation: vol 13 , Issue . p. 69-76.

Wolfgang Glanzel and Urs Schepflin (1999) a Bibliometric Study of reference literature in the Science and social sciences: Information Processing and Management: An international Journal. 35 (1), 31-44 